\title{
Orthodontic Treatment Needs Based on Aesthetic Component (AC) among Adolescents in Medan
}

\author{
Siti Bahirrah, Mimi Marina Lubis, Hilda Fitria Lubis \\ Department of Orthodontics,Faculty of Dentistry, \\ Universitas Sumatera Utara, Medan, Indonesia \\ nyonyaindra@yahoo.com
}

\begin{abstract}
The prevalence of malocclusion in Indonesia is high while dental health behaviour among adolescents especially towards malocclusion is inadequate whereas health services has not been satisfied. One of the most used index, Index of Orthodontic Treatment Need which consists of aesthetic component and dental health component. The aim of this research was to identify orthodontic treatment need based on aesthetic component among adolescents in Medan. This is a descriptive research with crosssectional design. Two stage stratification cluster sampling method were used. Total sample in this research were 400 adolescents in Medan. The results of this research stated that distribution of treatment need based on aesthetic component among adolescents in Medan were 210 individual $(52.5 \%)$ for group AC 1-2 (no treatment needed), 112 individual (28\%) for group AC 3-4 (mild treatment needed), 41 individuals $(\mathbf{1 0 . 3 \% )}$ for group 5-7 (moderate treatment needed) and 37 individuals $(9.3 \%)$ for group AC 8-10 ( great need for treatment).The conclusion from this research stated that most of the adolescents in Medan do not require orthodontic treatment.
\end{abstract}

Keywords-treatmen $t$ need index, aesthetic component, adolescents

\section{INTRODUCTION}

Based on the National health research in 2013, 14 province as much as $25.9 \%$ were facing oral health problems. The prevalence of malocclusion in Indonesia were still high about $80 \%$ from total population becoming major oral health problem. The prevalence if malocclusion among adolescents in Indonesia is still high, ranging from $90 \%$ in 1983 to $89 \%$ in 2006[1].As for the prevalence of malocclusion among adolescents in few countries was found to be $16.4 \%$ in Saudi Arab in $1990,11 \%$ in Kenya in 1993 and $19.6 \%$ in Punjab. Based on the research by Taylor, Kang et al stated that malocclusion affects the quality of life among adolescents [2-5].

Based on the data seen that dental health behaviour especially towards malocclusion is inadequate among adolescents whereas health services has not been satisfied.Besides correcting the tooth disharmony, orthodontic treatment is also considered a trend. Trend of using fixed orthodontic appliances usually happens in general population especially among the adolescents.
Adolescents psychologically have the desire to perform the best, love themselves and desire to gain recognition from the surrounding environment [6,7]. There are many index to evaluate orthodontic treatment needs but Index of Orthodontic Treatment Need (IOTN) is one of the most used index. IOTN was developed by Brook and Shaw in 1989 which consists of two components such as Dental Health Component (DHC) and Aesthetic Component (AC). Dental Health Component (DHC) was used to evaluate several types of malocclusion and Aesthetic Components were used to view the dental aesthetic of the patient in the form of photography. In other words that Aesthetic Component represents the state of a person's dental aesthetic prior to orthodontic treatment [6-10].

AC consists of 10 colored photograph scales showing the state of teeth with different levels in general, there are two ways to perform AC examination such as using a mirror or camera. The use of a mirror is done when the subject is asked to see the state of his teeth through a mirror Then the subject is asked to identify the AC closest to the state his anterior part of teeth. The use of cameras is done by taking intraoral photos of the anterior teeth. Assessment of AC is done subjectively and is not affected by the colour of the tooth, oral hygiene, or gingival condition. The value 1 shows favourable tooth arrangement whereas value 10 shows the most unfavourable tooth arrangement. The result from examination of $\mathrm{AC}$ is divided into three categories.

The value 1-4 indicates little or no need of care, the value 5-7 indicates borderline care, thevalue 8-10 indicates real need of care [8-11].

There are several studies conducted to look at the need for orthodontic treatment in adolescents. Research conducted by Bhardwaj et al stated that orthodontic treatment needs based on sex by using Dental Aesthetic Index (DAI) among adolescents in Shimla City, India showed that $80 \%$ with no abnormality or minor malocclusion, $16.16 \%$ with real malocclusion, $3.5 \%$ with severe malocclusion and $0 \%$ with very severe malocclusion in male subjects. In female subjects, $78.98 \%$ with no abnormality or minor malocclusion, $16.73 \%$ with real malocclusion, $3.5 \%$ with severe 
malocclusion and $0.77 \%$ with very severe malocclusion [11].

The research conducted in Tareandesa Rumoong junior high school in 2014 stated that Aesthetic Component (AC) were $73.77 \%$ with no need for orthodontic treatment, $22.95 \%$ with borderline treatment required and $3.28 \%$ with real treatment required [12]. Research conducted by Rumampuk in 2013 in BItung junior highschool showed that subjects which needed orthodontic treatment based on aesthetic component (AC) was 4.4\%, 19\% with borderline treatment needed and $76.6 \%$ with no need for orthodontic treatment [13]. Research using aesthetic component (AC) also conducted at Banda Aceh senior high school showed that subjects with no need for orthodontic treatment were 331 subjects $(86 \%)$, subjects with moderate orthodontic treatment needed were 47 subjects $(12.2 \%)$ whereas subjects with real orthodontic treatment needed were 7 subjects (7\%) [14].

Based on the above, the writer wishes to conduct a research about the orthodontic treatment needs among adolescents in Medan based on Aesthetic Component as there were still no data available regarding orthodontic treatment needs among adolescents in Medan. Medan is one of the metropolitan city in Indonesia with level of economic, social and cultural pluralism.

\section{MATERIALS AND METHODS}

This is a descriptive research with cross sectional design. Two stage stratification cluster sampling method were used. The population of this research were students from government and private high school in Medan. Total sample used in this research were 400 subjects. The inclusion criteria for this research are students with at least 28 fully erupted permanent tooth and no previous orthodontic treatment, no caries, gum or periodontal problems and no missing anterior tooth.This research obtain the approval from ethical commissions from the medical faculty in University of North Sumatera. Intra oral photographs were taken with digital camera on all samples. The intra oral photograph were measured with the scale of 1-10.

Aesthetic Component (AC) from Index of Orthodontic Treatment (IOTN).There scale of Aesthetic Component (AC) from Index of Orthodontic Treatment Need) ranging from 1 to 10 were shown in Figure 1, in which:

$$
\begin{array}{ll}
- & \mathrm{A}^{1-2}=\text { no need of treatment } \\
- & \mathrm{A}^{3-4}=\text { Mild treatment needed } \\
- & \mathrm{B}=\text { Borderline treatment needed } \\
- & \mathrm{C} \quad=\text { Real treatment needed }
\end{array}
$$

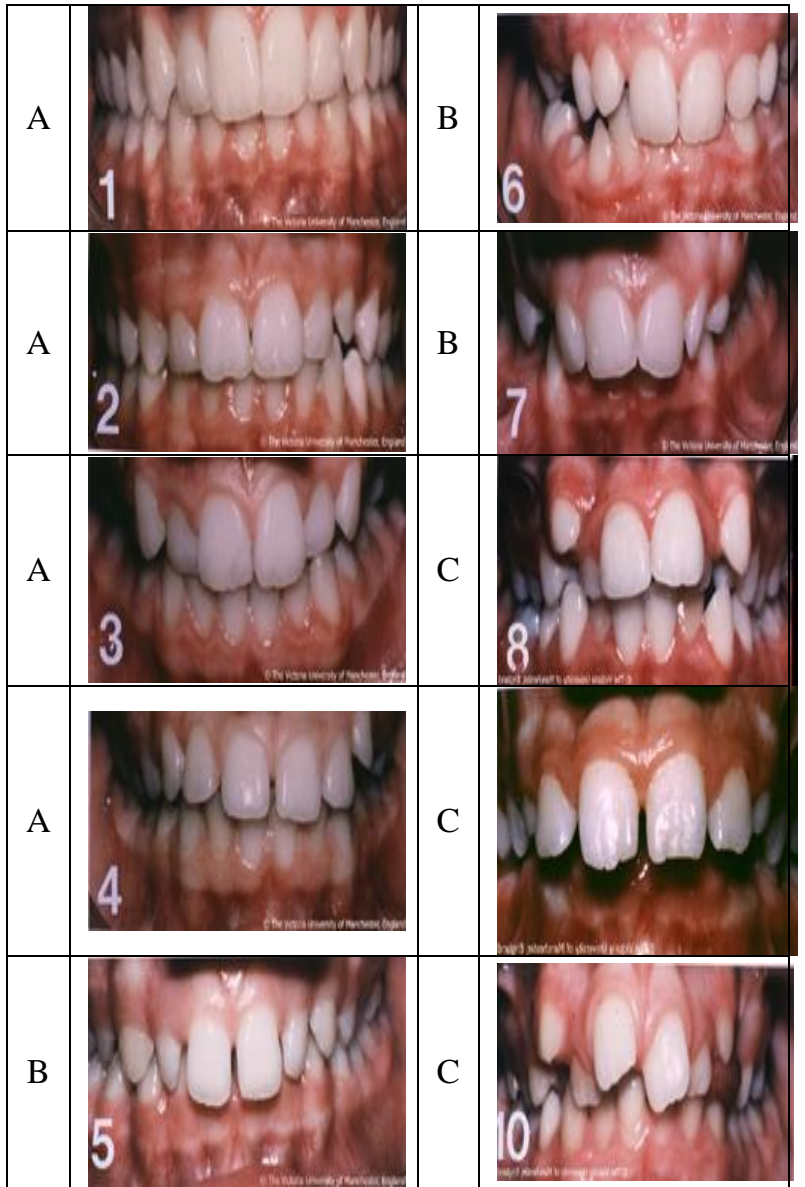

Figure 1.10 colored photograph scales showing the state of teeth with different levels in general.

\section{RESULTS}

This research had obtained a total of 400 samples. Distribution of the samples based on gender among adolescents in Medan are as shown in Table I.

TABLE I. DISTRIBUTION OF RESEARCH SAMPLES

\begin{tabular}{|c|c|}
\hline Gender & Total (n) \\
\hline Male & 202 \\
\hline Female & 198 \\
\hline
\end{tabular}

Based on table I, total participantsin accordance with the inclusion criteria in this research are as much as 400 samples. The number of male adolescents (202) are higher than female adolescents (198).

TABLE II. DISTRIBUTION OF THE ORTHODONTIC
TREATMENT NEED AMONG ADOLESCENTS
IN HIGHSCHOOL OF MEDAN
\begin{tabular}{|c|c|c|c|}
\hline Orthodontic treatment needs & AC & Total & Percentage \\
\hline No Need & $1-2$ & 210 & 52.5 \\
\hline Mild Treatment & $3-4$ & 113 & 28 \\
\hline Borderline Treatment & $5-7$ & 42 & 10.5 \\
\hline Real Need & $8-10$ & 36 & 9 \\
\hline
\end{tabular}

Based on Table II, it is clearly stated that overall distribution of Aesthetic Component among 400 adolescents in Medan. The largest distribution of AC among the adolescents in Medan were 210 samples (52.5\%) in group AC 1-2 (no treatment need), followed by group AC 3-4 (mild treatment needed) with 113 
samples (28\%), 42 samples (10.5\%) with group AC 5-7 (borderline treatment needed), and the least in group AC 8-10 (real treatment needed) with 36 samples (9\%).

TABLE III. DISTRIBUTION OF ORTHODONTIC TREATMENT NEED BASED ON AC IN BOTH GENDERS AMONG ADOLESCENTS IN MEDAN

\begin{tabular}{|c|c|c|c|c|c|c|c|}
\hline \multirow{3}{*}{$\begin{array}{c}\text { Category } \\
\text { AC }\end{array}$} & \multicolumn{4}{|c|}{ Gender } & \multicolumn{2}{|c|}{ Total } & \multirow[t]{3}{*}{$\mathbf{p}$} \\
\hline & \multicolumn{2}{|c|}{ Male } & \multicolumn{2}{|c|}{ Female } & $\mathbf{N}$ & $(\%)$ & \\
\hline & $\mathbf{N}$ & $(\%)$ & $\mathbf{N}$ & $(\%)$ & & & \\
\hline No Need & 161 & 40.25 & 161 & 40.25 & 323 & 80.5 & \\
\hline Borderline & 24 & 6 & 18 & 4.5 & 42 & 10.5 & 0320 \\
\hline Real Need & 22 & 5.5 & 14 & 3.5 & 36 & 9 & 0.330 \\
\hline Total & 207 & 51.75 & 193 & 48.25 & 400 & 100 & \\
\hline
\end{tabular}

Based on Table III showed that, male which do not required any treatment were 161 samples (40.25\%), required borderline treatment were 24 samples (6\%) and required real treatment were 22 samples (5.5\%). In female which do not required any treatment were 161 samples $(40.25 \%)$, required borderline treatment were 18 samples $(4.5 \%)$ and required real treatment were 14 samples $(3.5 \%)$.

TABLE IV. DISTRIBUTION OF ORTHODONTIC TREATENT NEED BASED ON AC AMONG ADOLESCENTS IN GOVERNMENT AND PRIVATE SCHOOLS IN MEDAN

\begin{tabular}{|c|c|c|c|c|c|c|}
\hline \multirow{2}{*}{$\begin{array}{c}\text { Orthodontic } \\
\text { Treatment } \\
\text { Needs }\end{array}$} & \multicolumn{4}{|c|}{ High Schools } & \multicolumn{2}{c|}{ Total } \\
\cline { 2 - 7 } & Government & \multicolumn{2}{c|}{ Private } & N & $(\boldsymbol{\%})$ \\
\hline No Need & 161 & 40.25 & 161 & 40.25 & 322 & 80.50 \\
\hline Borderline & 25 & 6.25 & 17 & 4.25 & 42 & 10.50 \\
\hline Real Need & 15 & 3.75 & 21 & 5.25 & 36 & 9 \\
\hline Total & 201 & 50.25 & 199 & 49.75 & 400 & 100 \\
\hline
\end{tabular}

Based on Table IV showed that, level of orthodontic treatment needs among the adolescents in government school were 161 samples $(40.25 \%)$ with no need of treatment, 25 samples $(6.25 \%)$ which required borderline treatment and 15 samples $(3.75 \%)$ which required real treatment. Whereas among adolescents in private highschools, 161 samples $(40.25 \%)$ with no need of treatment, 17 samples $(4.25 \%)$ required borderline treatment and 21 samples $(5.25 \%)$ which required real treatment.

TABLE V. DIFFERENCE IN ORTHODONTIC TREATMENT NEEDS BASED ON AC IN BOTH GENDERS AMONG ADOLESCENTS IN MEDAN

\begin{tabular}{|c|c|c|c|c|c|c|c|}
\hline \multirow{2}{*}{$\begin{array}{c}\text { Category } \\
\text { AC }\end{array}$} & \multicolumn{4}{|c|}{ Male } & \multicolumn{2}{|c|}{ Female } & \multicolumn{2}{|c|}{ Total } & \multirow{2}{*}{$\mathbf{*}$} \\
\cline { 2 - 6 } & $\mathbf{N}$ & $\mathbf{( \% )}$ & $\mathbf{N}$ & $\mathbf{( \% )}$ & & \\
\hline No Need & 161 & 40.25 & 161 & 40.25 & 323 & 80.5 & \\
\hline Borderline & 24 & 6 & 18 & 4.5 & 42 & 10.5 & \multirow{2}{*}{0.330} \\
\hline Real Need & 22 & 5.5 & 14 & 3.5 & 36 & 9 & \\
\hline Total & 207 & 51.75 & 193 & 48.25 & 400 & 100 & \\
\hline
\end{tabular}

Based on the result in Table $\mathrm{V}$, there is no significant difference between male and female towardsorthodontic treatment needs based on aesthetic component scale from IOTN where $\mathrm{p}=0.330$.
TABLE VI. DIFFERENCE IN ORTHODONTIC TREATMENT NEEDS BASED ON AC AMONG ADOLESCENTS IN GOVERNMENT AND PRIVATE SCHOOLS IN MEDAN

\begin{tabular}{|c|c|c|c|c|c|c|c|}
\hline \multirow{3}{*}{$\begin{array}{c}\text { Category } \\
\text { AC }\end{array}$} & \multicolumn{4}{|c|}{ School (SMU) } & \multicolumn{2}{|c|}{ Total } & \multirow{3}{*}{$p$} \\
\hline & \multicolumn{2}{|c|}{$\begin{array}{c}\text { SMU } \\
\text { Negeri }\end{array}$} & \multicolumn{2}{|c|}{$\begin{array}{c}\text { SMU } \\
\text { Swasta } \\
\end{array}$} & \multirow[t]{2}{*}{$\mathbf{N}$} & \multirow[t]{2}{*}{$(\%)$} & \\
\hline & $\mathbf{N}$ & $(\%)$ & $\mathbf{N}$ & $(\%)$ & & & \\
\hline No Need & 161 & 40.25 & 161 & 40.25 & 322 & 80.50 & \multirow{4}{*}{$0.283^{\mathrm{a}}$} \\
\hline Borderline & 25 & 6.25 & 17 & 4.25 & 42 & 10.50 & \\
\hline Real Need & 15 & 3.75 & 21 & 5.25 & 36 & 9 & \\
\hline Total & 201 & 50.25 & 199 & 49.75 & 400 & 100 & \\
\hline
\end{tabular}

Based on the results in Table VI, there is no difference between adolescents in government and private schools in Medan towards orthodontic treatment needs where $\mathrm{p}=0.283$.

\section{DISCUSSION}

This research is carried out in the high schools in Medan. The reason behind using the samples from high schools is students in high schools are still categorized as adolescents ranging from 15-18 years old. Samples which fulfilled the inclusion criteria were 400 samples and consists of 202 male adolescents and 198 female adolescents. This orthodontic treatment needs research evaluate based on Aesthetic Component (AC) from IOTN. AC consists of 10 scaled coloured photo which consists of 3 categories such as no need of treatment, borderline treatment needed and real treatment needed. Evaluation based on AC have many advantages such as patients are motivated to undergo orthodontic treatment as they can view their tooth condition subjectively. Results in table 2 shows that orthodontic treatment needs based on aesthetic component (AC) such as no need of treatment /mild treatment needed as much as $80.5 \%$, borderline treatment needed as much as $10.3 \%$ and real treatment needed as much as $9.3 \%$. This results is supported by other research on adolescents in other countries and few cities in Indonesia. The research conducted by Trivedi et al in 2011 on the adolescents in Udaipur where adolescents with no need of treatment were $78 \%$, borderline treatment needed were $18 \%$, and real treatment needed were $4 \%$.

The research by Wilar in 2014 in Tarean government junior high schools found that $73.77 \%$ of the samples with no need or mild treatment needed, $22.95 \%$ with borderline treatment needed and $3.28 \%$ with real treatment needed. The research based on aesthetic component conducted in Banda Aceh government senior high schools also shows similar results where $86 \%$ with no need or mild treatment needed, $12.2 \%$ with borderline treatment needed and $1.8 \%$ with real treatment needed. The level of orthodontic treatment needs among adolescents in Medan or adolescents in other cities or countries also shows similar results where no need for treatment/ mild treatment needed are the category with the largest percentage [12].

The results based on genders also showed no significant differences between male and female towards the orthodontic treatment needs based on AC 
where $p$ value $=0.33(\mathrm{p}>0.05)$. This result of this research were in accordance with the research by Fariba' and Sirous in 2011 conducted in Zahedan city on 395 adolescents with aged $11-14$ years old which consists of 198 male adolescents and 197 female adolescents. In their research found that $p$ value 0.23 ( $p>0.05)$, which means that there is no significant difference in orthodontic treatment needs based on AC between male and female adolescents in the school of Zahedan city [15].

This results differs from the research by Oley et al where the necessity of real orthodontic treatment needed in male group were higher than the female group[16]. Based on the research conducted by AlZubair et al in 2015 in Sana city, Saudi Arabia found that level of concern towards dental health and maintenance of tooth condition in male were lower compared to female. Besides that, male felt more satisfied with the aesthetics of their tooth as compared to the females [17].

This research also compares the differences in orthodontic treatment needs based on AC among adolescents in government and private schools found that the results were not significant where $\mathrm{p}=0.283$ $(p>0.05)$. In other words, social economy status have no effect towards the evaluation of orthodontic treatment needs based on the AC scale because evaluation of AC is related to individual perception. Evaluation towards the AC scale determines the level of orthodontic treatment needs. Based on the research by Albarakti in 2014 in East Nepal found that mostof the subjects tend to evaluate their tooth condition better than their actual condition which leads to inaccuracies from the measurements [18].

From the result of the research, we can conclude that the need for treatment among adolescents in Medan based on aesthetic component are the highest in group where no need for treatment or mild treatment needed.

\section{ACKNOWLEDGMENTS}

The authors gratefully acknowledge that the present research is supported by Ministry of Research and Technology and Higher Education Republic of Indonesia. The support is under the research grant DIPA of Year 2016 Contract Number 017/SP2H/LT/DRPM/2/2016.

\section{REFERENCES}

[1] T.D. Foster, A textbook of orthodontics, $3^{\text {rd }}$ ed., Austria: Blackwell Scientific, 1990, pp. 24, 179-180.
[2] D. Chauhan, V. Sachdev, T. Chauhan, K.K. Gupta, "A study of malocclusion and orthodontic treatment needs according to dental aesthetic index among school children of a Hilly State of India," International Society of Preventive \& Community Dentistry, vol. 3(1), pp. 32-37, 2013.

[3] O. Dewi, Analisis hubungan maloklusi dengan kualitas hidup pada remaja SMU Kota Medan tahun 2007, Tesis, Medan: USU, 2008, pp. 14-24.

[4] S.C. Mantiri, V.N.S. Wowor, P.S. Anindita, "Status kebersihan mulut dan status karies gigi mahasiswa pengguna alat ortodonti cekat," Jurnal e-GiGi, vol. 1(1), pp. 1-7, 2013.

[5] L.A King, The science of psychology: an appreciative view, Alih Bahasa: B. Marwensdy, Jakarta: Salemba Humanika, 2010, pp. 188-198, 204-205.

[6] K. Fudyartanta, Psikologi perkembangan, Yogyakarta: Pustaka Pelajar, 2011, pp. 201-220.

[7] J.B. Mark, The efficacy of training dental students in the index of orthodontic treatment need (IOTN), Tesis, Ohio: The Ohio State University, 2000, pp. 2-29.

[8] M.C. Flores, P.W. Major, "Self-perceived orthodontic treatment need evaluated through 3 scales in a university population," J. Orthod., vol. 31, pp. 329-334, 2004

[9] V. Malik, S. Grover, S.S. Maninder, et al. "Evaluation of orthodontic treatment need and its correlation with the perception, awareness and satisfaction of personal dental apperance among dental students," Journal of Orofacial Research, vol. 3(1), pp. 5-11, 2013.

[10] T. Kalyani, R.S. Tarulatha, D. Jigar, R. Yagnesh,"Realibility of aesthetic component of IOTN in the assessmentof subjective orthodontic treatment need," Journal of Advanced Dental Research, vol. 2(1), pp. 59-66, 2011.

[11] V.K. Bhardwaj, K.L. Veeresha, K.R. Sharma, "Prevalence of malocclusion and orthodontics treatment needs among 16 and 17 years old school going children in Shimla City, Himachal Pradesh,” Indian Dental Journal, vol. 22(4), pp. 556-560, 2011.

[12] L.A. Wilar, A.J.M. Rattu, N.W. Mariati, "Kebutuhan perawatan orthodonsi berdasarkan index of orthodontic treatment need pada siswa SMP Negeri 1 Tareran," Jurnal eGigi, vol. 2(2), Juli 2014

[13] A. Juliza. (2015, January 9) Kebutuhan perawatan ortodonti pada remaja $\mathrm{RN}$ usia 15-17 tahun berdasarkan penilaian aesthetic component dari IOTN. Available: http://222.124.186. 246:8885/index.php?p=show_detail\&id=9303

[14] A. Djunaid, N.P. Gunawan, A.J. Khoman, "Gambaran pengetahuan tentang tampilan maloklusi pada siswa sekolah menengah pertama Kristen 67 Imanuel Bahu. Jurnal e-Gigi (eG), vol 1(1), pp. 28-31, Maret 2013.

[15] S. Fariba, R. Sirous. (2014, September 15) Use of the index of orthodontic treatment need in the school population of Zahedan. Available: http://bos.org.uk.

[16] A.B. Oley, P.S. Anindita, M.A. Leman, "Kebutuhan perawatan ortodonti berdasarkan index of orthodontic treatment need pada usia remaja 15-17 tahun,” Jurnal e-Gigi (eG), vol. 3(2), 292-297, 2015.

[17] N.M Al-Zubair, F.A. Idris, F.M. Al-Selwi, "The subjective orthodontic treatmentneed assessed with the aesthetic component of the index of orthodontic treatment need," The Saudi Journal for Dental Research, vol. 6, pp. 9-14, 2015.

[18] S.F. Albarakati, "Self perception of malocclusion of Saudi patients using the aesthetic component of the IOTN index," Pakistan Oral Dent J., vol. 27, pp. 45-52, 2001. 